\author{
Ye.M. Tazhbayev ${ }^{1}$, T.S. Zhumagalieva ${ }^{1}$, L.Zh. Zhaparova ${ }^{1}$, A.A. Agdarbek ${ }^{1}$, \\ E.Zh. Zhakupbekova ${ }^{1}$, G.K. Burkeeva ${ }^{1}$, B.N. Karimova ${ }^{2}$, S.B. Zhautikova ${ }^{3}$ \\ ${ }^{I}$ E.A. Buketov Karaganda State University, Kazakhstan; \\ ${ }^{2}$ Karaganda Economic University of the Kazpotrebsoyuz, Kazakhstan; \\ ${ }^{3}$ Medical University of Karaganda, Kazakhstan \\ (E-mail: aagdarbek@gmail.com)
}

\title{
Synthesis and investigation of PLGA-based nanoparticles as a modern tool for the drug delivery
}

\begin{abstract}
The possibility of immobilization of the «Tamoxifen» antitumor drug in polylactide glycolide nanoparticles was shown in this study. Nanoparticles based on a biodegradable and biocompatible polylactide glycolide polymer were prepared by the simple emulsion method. Various concentrations of the drug substance and stabilizer were studied to obtain nanoparticles with the best physico-chemical parameters (particle size, polydispersity, degree of binding and release, biodegradation). Polyvinyl alcohol was used as a stabilizer in the present work. The sizes of polymer nanoparticles determined by dynamic light scattering vary from $226.7 \mathrm{~nm}$ to $397.2 \mathrm{~nm}$ with a narrow size distribution (the polydispersity (PDI) values were $0.01-0.2$ ). The degree of «Tamoxifen» binding to the polymer calculated by the UV spectrophotometric method $(\lambda=275.5 \mathrm{~nm})$ was about $82 \%$, which makes it promising for application in drug delivery. The shape and morphology of nanoparticles were studied with the help of scanning electron microscopy. The kinetics of drug release from polylactide glycolide nanoparticles was studied under conditions simulating a biological medium. The general character of the biodegradation of polylactide glycolide nanoparticles immobilized by «Tamoxifen» was also studied by a viscometric method at different $\mathrm{pH}$ values and at $310 \mathrm{~K}$.
\end{abstract}

Keywords: nanoparticles, polymer nanoparticles, polylactide glycolide, tamoxifen, simple emulsion method, immobilization, drug delivery, polymers.

\section{Introduction}

At present modern pharmacotherapy is known to have many powerful drugs, but the results of treatment often remain unsatisfactory. One of the factors that reduce the effectiveness of drugs is unfavorable biodistribution, which can be due to difficulties in penetrating the focus of the pathology; which in turn leads to low therapeutic effect. The relevance of this problem served as an incentive for the development of approaches to the creation of various systems of targeted delivery of drugs. Polymer nanoparticles are of particular interest among such systems. These are particles ranging in size from 10 to $1000 \mathrm{~nm}$, combining qualities important for carriers, such as stability and high capacity in relation to a wide range of drug substances.

Treatment of cancer based on nanotechnology has become one of the promising areas of biomedicine that has been widely studied over the past few decades for providing effective and targeted delivery of chemotherapeutic agents which allows to reduce the dose of the drug and minimize non-specific side effects. Nanomedicine in the field of cancer treatment overcomes the shortcomings of traditional drug delivery systems, such as nonspecific biodistribution and targeting, lack of solubility in water, low oral bioavailability and low therapeutic parameters [1-3].

Various drug carriers (e.g., micelles, liposomes, and polymer-drug conjugates) have been developed to enhance tumor targeting, drug delivery and controlled release in the past few decades. In particular, polymer particles are of great interest in targeting a tumor site for application in cancer therapy. Nanoparticles can be attached to small molecules of drugs and serve as drug carriers for delivering molecules to the targeted region in the human body [4].

Polymers based on natural hydroxy acids such as glycolic, lactic, malic acid, etc. capable of degrading in human body into harmless substances, are widely used as drug delivery systems [5]. Micro and nanoparticles based on polyglycolic, polylactic acids, their copolymers and esters are used for targeted delivery of drugs for a wide variety of purposes. It was established that the ratio of lactide and glycolide units in the polymer affected the release of the drug [6]. The release rate of hydrophilic preparations increases with an increase in the content of glycolide units and decreases for lipophilic ones, if the release occurs before the polymer degradation process. 
An important feature of polylactides and polyglycolides is biocompatibility with human body tissues which is due to enzymatic degradation of ester bonds based on derivatives of lactic and glycolic acids.

It has been established that polylactides with hydrophobic end groups degraded 2.7 times faster in vitro and 4 times faster in vivo than polymers with hydrophilic groups [7]. A copolymer based on lactic and glycolic acids [50/50 poly-( $d, l$-lactide-co-glycolide) (nominal)] is non-toxic and undergoes biodegradation in the human body with the formation of lactic and glycolic acids, the catabolism of which ends with the formation of carbon dioxide and water [8].

In this regard, the purpose of this work was to study the possibility of binding nanoparticles of poly-(d,l-lactide-co-glycolide) with the «Tamoxifen» antitumor drug in order to prolong its therapeutic efficacy and reduce undesirable toxic effects.

\section{Experimental}

Preparation of poly-(d,l-lactide-co-glycolide) nanoparticles loaded with Tamoxifen drug substance by the simple emulsion method

The poly-(d,l-lactide-co-glycolide) copolymer (PLGA) nanoparticles loaded with Tamoxifen drug were prepared by the emulsion method, followed by solvent evaporation according to the following procedure. The calculated amount of polymer was dissolved in an organic solvent, namely chloroform. The drug substance was also dissolved in a mixture of ethyl alcohol and chloroform. The solvent mixture was combined to form a diffusion phase. Then, the diffusion phase was added dropwise to the dispersing phase for ten minutes by emulsification using an Ultra-Turrax T-10 homogenizer (IKA, Germany) with a syringe located directly in the medium. The resulting oil-water emulsion was analyzed for particle size by photon correlation spectroscopy (PCS). Then it was stirred on a magnetic stirrer for several hours at room temperature until all of the organic solvent evaporated, leaving the cured nanocapsules in an aqueous medium.

Newly formed nanoparticles were centrifuged 2 times for 30 minutes at $14100 \mathrm{rpm}$ (miniSpinplus 14500 centrifuge, Eppendorf, Germany) and washed with distilled water to remove all unbound drug.

\section{Determination of particle size and polydispersity}

The average nanoparticle size and their polydispersity were determined by the PCS method on a Malvern Zetasizer Nano S90 instrument (Malvern Instruments Ltd., UK) at $298 \mathrm{~K}$ and $90^{\circ}$ scattering angle. Each nanoparticles sample was properly diluted immediately after preparation with a non-solvent. The average size and polydispersity were measured three times for each series.

Determination of the binding degree and drug release of Tamoxifen from PLGA nanoparticles.

The binding of tamoxifen with nanoparticles was determined by the concentration of the drug in the solution of the centrate. An analysis of the solution of the centrate was performed on UV-1800 SHIMADZU using UV spectrophotometry $(\lambda=275.5 \mathrm{~nm})$. The solutions were diluted with water before measurement. An in vitro drug release study was carried out in phosphate-buffered saline $(\mathrm{pH}=5.4 ; \mathrm{pH}=7.4)$ at $310 \mathrm{~K}$ for 3 days. Samples were removed from a thermostat and analyzed using UV spectrophotometry.

\section{Results and Discussion}

The emulsion method is used for polymers having hydrophobic properties. It is based on the dissolution of the amphiphilic polymer in an organic solvent followed by the addition of water to form the primary emulsion, after which it is homogenized or sonicated to obtain a finely dispersed emulsion. The formation of an emulsion is one of the key aspects of this method, due to the fact that the size of the droplets of the emulsion is directly related to the size of the particles. It is connected with the curing of the particles after evaporation of the organic solvent. Drug loading into nanoparticles of a PLGA copolymer was carried out as described above.

Different concentrations of drugs (5 and $10 \mathrm{mg} / \mathrm{ml})$ and surfactants $(0.5 \% ; 1 \%$ and $2 \%)$ were used to obtain polymer nanoparticles with satisfactory physico-chemical characteristics. As a result of encapsulation of Tamoxifen in PLGA nanoparticles, the obtaned emulsion had a white tint without visible delamination. The particles were analyzed for particle size by the PCS method directly after homogenization. The results of the study of physico-chemical parameters of polymer nanoparticles are presented in Table 1.

The experimental results show that an increase in the concentration of the stabilizer leads to a shift in the distribution towards large diameters. This is due to an excess of surfactants. Large particles and agglomerates are formed when encapsulating the drug with a concentration of $5 \mathrm{mg} / \mathrm{ml}$ in the polymer matrix in the presence of $1 \%$ and $2 \%$ surfactant. A decrease in the concentration of PVA $(0.5 \%)$ and an increase in the concentration 
of drugs $(10 \mathrm{mg} / \mathrm{ml})$ lead to positive results, namely nanosized particles $(200-300 \mathrm{~nm})$ were formed. The PDI polydispersity index for all particles stabilized by PVA did not exceed 0.2 .

$\mathrm{Tab} 1 \mathrm{e} 1$

Physico-chemical characteristics of PLGA nanoparticles immobilized by «Tamoxifen»

\begin{tabular}{|c|c|c|c|c|c|c|c|}
\hline \multirow{2}{*}{$\begin{array}{c}\text { PVA, } \\
\%\end{array}$} & \multirow{2}{*}{$\begin{array}{c}\mathrm{DS}, \\
\mathrm{mg} / \mathrm{ml}\end{array}$} & \multirow{2}{*}{$\begin{array}{c}\text { Average particle size, } \\
\mathrm{d}, \mathrm{nm}\end{array}$} & \multirow{2}{*}{$\begin{array}{c}\text { NPs Polydispersity } \\
\text { (PDI) }\end{array}$} & \multirow{2}{*}{$\begin{array}{r}\text { Degree of } \\
\text { binding, } \%\end{array}$} & \multirow{2}{*}{$\begin{array}{c}\text { NPs yield, } \\
\%\end{array}$} & \multicolumn{2}{|c|}{ Degree of release, $\%$} \\
\hline & & & & & & $\mathrm{pH}=5.4$ & $\mathrm{pH}=7.4$ \\
\hline \multirow{4}{*}{0.5} & \multirow{4}{*}{10} & 226.7 & 0.215 & \multirow{4}{*}{69.0} & \multirow{4}{*}{52} & \multirow{4}{*}{25.3} & \multirow{4}{*}{34.1} \\
\hline & & 225.4 & 0.189 & & & & \\
\hline & & 226.2 & 0.206 & & & & \\
\hline & & $226.1 \pm 0.66$ & $0.203 \pm 0.013$ & & & & \\
\hline \multirow{7}{*}{1} & \multirow{3}{*}{5} & 485.2 & 0.054 & \multirow{3}{*}{82.6} & \multirow{3}{*}{73} & \multirow{3}{*}{-} & \multirow{3}{*}{90.4} \\
\hline & & 486.3 & 0.125 & & & & \\
\hline & & $\frac{483.8}{485.1 \pm 1.25}$ & $0.111 \pm 0.051$ & & & & \\
\hline & \multirow{4}{*}{10} & 397.2 & 0.011 & \multirow{4}{*}{62.0} & \multirow{4}{*}{68} & \multirow{4}{*}{21.4} & \multirow{4}{*}{30.2} \\
\hline & & 396.5 & 0.121 & & & & \\
\hline & & 395.8 & 0.136 & & & & \\
\hline & & $396.5 \pm 0.70$ & $0.089 \pm 0.068$ & & & & \\
\hline \multirow{4}{*}{2} & \multirow{4}{*}{5} & 779.2 & 0.244 & \multirow{4}{*}{78.0} & \multirow{4}{*}{61} & \multirow{4}{*}{ - } & \multirow{4}{*}{38.0} \\
\hline & & 778.3 & 0.298 & & & & \\
\hline & & 780.1 & 0.321 & & & & \\
\hline & & $779.2 \pm 0.90$ & $0.288 \pm 0.040$ & & & & \\
\hline
\end{tabular}

Figure 1 shows the distribution curves of PLGA nanoparticles over diameters obtained by dynamic light scattering. It can be seen from the above figures that PLGA nanoparticles have satisfactory physico-chemical characteristics. The average particle size when using a PVA concentration of $0.5 \%$ is $226.1 \pm 0.66 \mathrm{~nm}$, for a PVA concentration of $1 \%$ is $396.5 \pm 0.70 \mathrm{~nm}$, the polydispersity value is 0.215 and 0.011 , respectively.

A monomodal particle size distribution was observed in both cases. The uniformity of sizes is an important problem in the preparation of nanoparticles, since the size affects the chemical and biological properties of the nanoparticles. The formation of particles less than $300 \mathrm{~nm}$ in size is preferable due to a more favorable pharmacological profile, prolonged kinetics in the circulatory system, and delayed release at the sites of action $[9,10]$.

Given the effectiveness of encapsulation of tamoxifen in nanoparticles (NPs), their size and polydispersity, PVA concentrations of $0.5 \%$ and $1 \%$ were selected for in vitro analysis of drug release and drug characteristics.

The determination of the degree of drug binding to polymer nanoparticles is an important indicator characterizing the quantitative volume of drug immobilization in polymer nanoparticles. The degree of binding of PLGA and tamoxifen nanoparticles was determined spectrophotometrically and calculated by the formula 1:

Degree of binding $=($ mass of drug substance in nanoparticles $) /($ total mass of drug $) \times 100 \%$.

The results presented above in Table 1 indicate a significant effect of the concentration of PVA on the most important characteristics of the system. The greatest values of encapsulation efficiency which were equal to $82.6 \%$ and $78.0 \%$ were observed at $1 \%$ and $2 \%$ concentrations of PVA respectively. But, despite the high degree of binding and release, these PVA concentrations were not considered, since the average particle size does not meet the requirements allowed for nanoparticles. Therefore, polymer NPs with the concentration of PVA equal to $0.5 \%$ and $10 \mathrm{mg}$ of the drug were selected as the most effective one. Moreover, the degree of binding was $69 \%$ for a $0.5 \%$ PVA concentration and the degree of binding was $62 \%$ for a $1 \%$ PVA concentration.

The PCS method allows one to establish the distribution of NPs by their hydrodynamic diameters in an aqueous suspension, while all particles are considered spherical. The method does not provide information on the shape of the particles. It is necessary to use a set of experimental methods for a more complete characterization of low frequencies. 


\begin{tabular}{|c|c|c|c|c|c|}
\hline & & & Size (d.nm): & $\%$ Intensity & Width (d.nm): \\
\hline Z-Average (d.nm): & 226,7 & Peak 1: & 308,0 & 100,0 & 192,2 \\
\hline Pdl: & 0,215 & Peak 2: & 0,000 & 0,0 & 0,000 \\
\hline Intercept: & 0,653 & Peak 3: & 0,000 & 0,0 & 0,000 \\
\hline Result quality : & Good & & & & \\
\hline
\end{tabular}
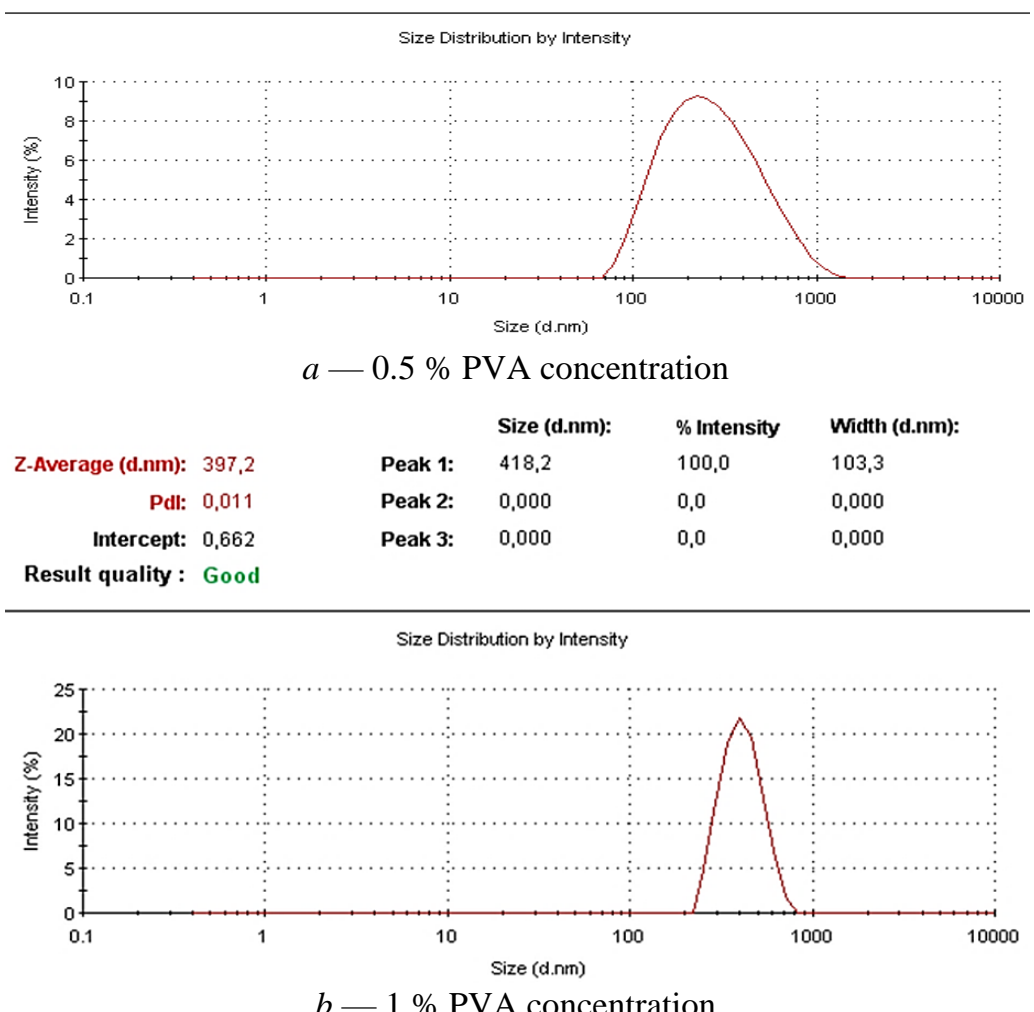

Figure 1. Particle size distribution of PLGA NPs immobilized by Tamoxifen stabilized with PVA

For this purpose a number of nanoparticles samples were additionally investigated by scanning electron microscopy. Morphological analysis of the samples was carried out with the help of a scanning electron microscope MIRA 3 LM TESCAN (Czech Republic) in the Laboratory of Electron Microscopy in collaboration with the staff of the Physico-Technical Faculty of the E.A. Buketov Karaganda State University. Electronmicroscopic images were taken to confirm the data obtained by the PCS method, which are presented in Figure $2(a)$ and $(b)$. Micrographs of nanoparticles samples show both single particles and their agglomerates. Systems mainly consist of particles of the same size in the range of 200-400 nm, however, larger particles (larger than $500 \mathrm{~nm}$ ) are also present in the system. We assume that they are formed in the process of aggregation of NPs upon evaporation of an organic solvent.

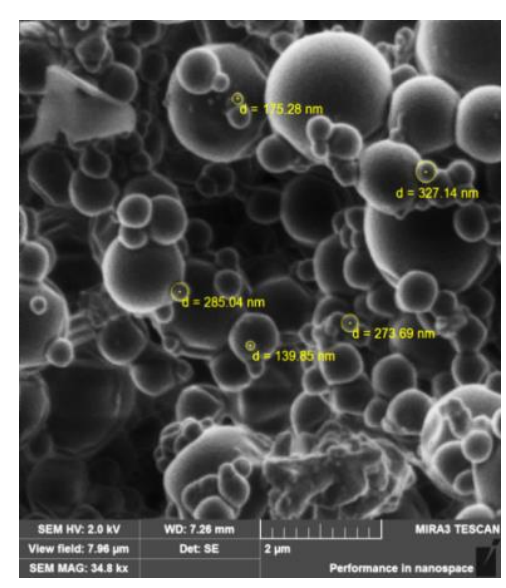

$a-0.5 \%$ PVA concentration

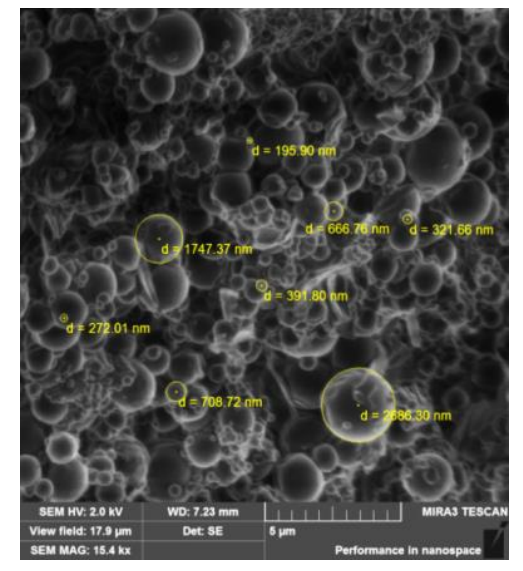

$b-1 \%$ PVA concentration

Figure 2. Microphotographs of PLGA-based NPs samples stabilized by PVA 
Decomposition of polymer-immobilized complexes in a biological environment is an important condition for their use. This is a prerequisite for the release of the drug from the polymer matrix as a result of the decomposition of polymer nanoparticles. In general, the mechanism of drug release from polymer nanoparticles may vary depending on the nature of the polymer. Decomposition of polymers can occur as a result of chemical destruction of the chain and mechanical destruction of polymer nanoparticles.

In this work, the destructive nature of PLGA nanoparticles was carried out by the viscometric method at $310 \mathrm{~K}$ temperature and various $\mathrm{pH}$ values (5.4 and 7.4). The results of the study of PLGA nanoparticles are presented in Figure 3.

The destruction of polymers occurs faster in vivo than in vitro, which is associated with biological effects, as well as with the formation of an immune response. Chemical bonds in the macromolecules are broke down in the process of destruction, and the degree of polymerization and the molecular weight of the polymer are reduced. As can be seen from the figures, the destruction of polymer nanoparticles occurs very slowly depending on time. As a result of the destruction of polylactide glycolide the glycolic and lactic acids are formed [5]. It is seen that the viscosity of the medium decreases depending on the $\mathrm{pH}$ of the medium as a result of the destruction of polylactide glycolide. And in the second system, that is, in a system with $1 \%$ PVA concentration (Fig. 3b), the destruction occurs very slowly, which is explained by a higher concentration of PVA and a larger particle size compared to the first concentration.
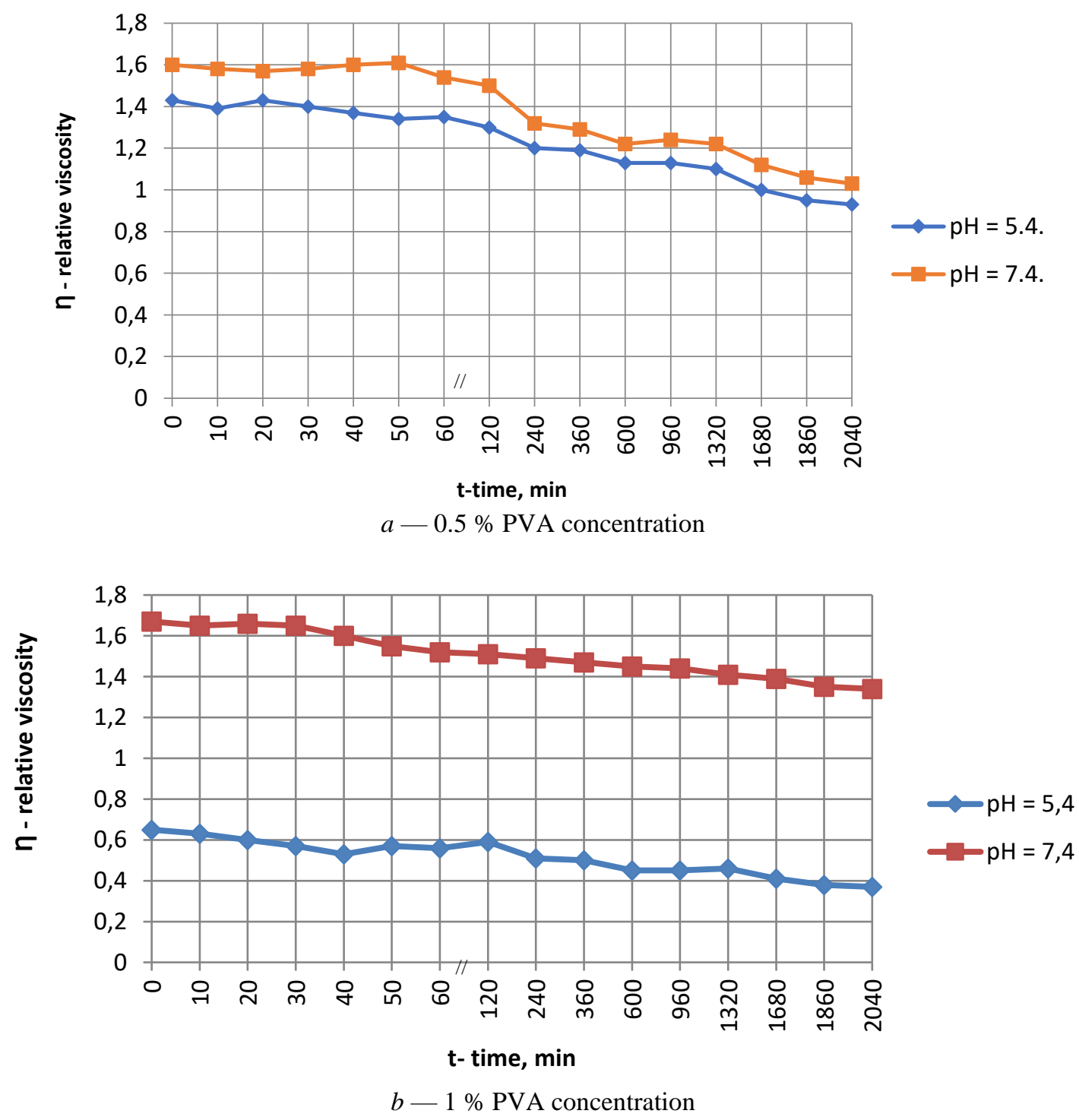

Figure 3. Viscometric study of the destruction of PLGA nanoparticles stabilized with PVA 
After studying the destruction by UV spectrophotometry, we analyzed the release profiles of tamoxifen from polymer nanoparticles for two samples, over 3 days, under conditions simulating a biological state, i.e., in a phosphate-buffered solution $(\mathrm{pH}=5.4 ; \mathrm{pH}=7.4)$ at $310 \mathrm{~K}$ temperature. The results are presented in Figure $4(a)$ and $(b)$.
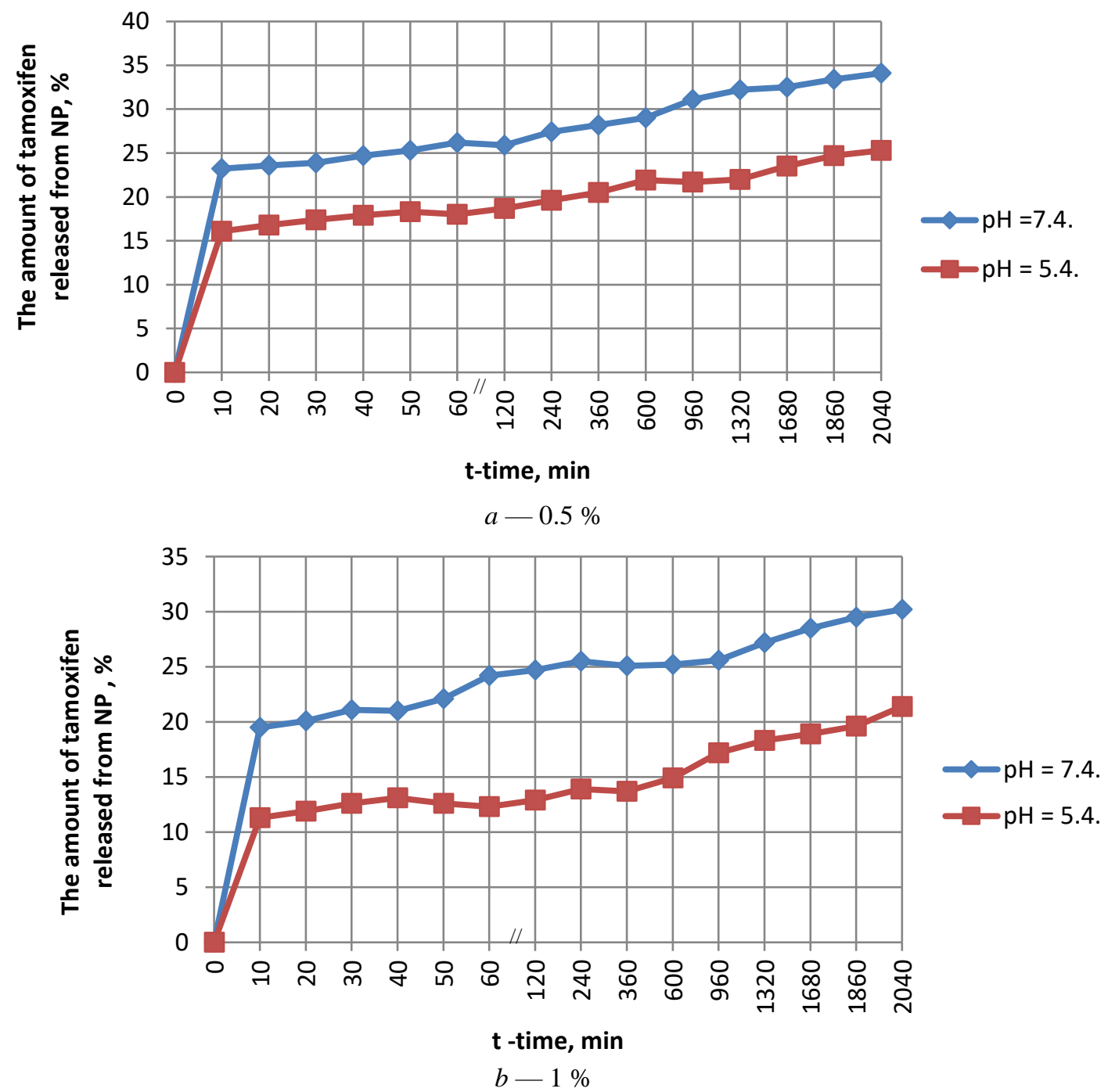

Figure 4. Dependence of the amount of Tamoxifen released from the PLGA NPs matrix obtained in the presence of PVA

It is seen from the presented data that approximately $20-30 \%$ of the drug was released within 72 hours from PLGA. In this case, the kinetics of drug release in the medium $\mathrm{pH}=7.4$ is higher than at $\mathrm{pH}=5.4$. A similar dependence was observed when studying the destruction of polymers. Studies have shown that drug release became much slower after 74 hours for all samples. An emergency release of the drug of about $10-$ $20 \%$ was observed for 10 minutes at the initial stage. Subsequently, the total yield of the drug reached 20$30 \%$ within 3 days.

\section{Conclusions}

Thus, PLGA nanoparticles immobilized by the anti-tumor drug «Tamoxifen» were obtained by the simple emulsion method. The nanoparticles synthesized have satisfactory physico-chemical characteristics, which makes them promising systems for drug delivery. The binding degree of polylactide-co-glycolide with antitumor drug «Tamoxifen» was 60-80\%. Kinetics of release of the drug has prolonged profile which gave opportunity to work out less toxic forms of «Tamoxifen» with longer period of action. 


\title{
References
}

1 Cai W., Gao T., Hong H., \& Sun J. Applications of gold nanoparticles in cancer nanotechnology / W. Cai, T. Gao, H. Hong, J. Sun // Nanotechnol. Sci. Appl. - 2008. - Vol. 1, No. 1. - P. 17-32.

2 Burkeev M.Zh. Synthesis and investigation of nanoparticles of poly-d,l-lactic acid loaded with antituberculosis drug preparation «Isoniazid» / M.Zh. Burkeev, Ye.M. Tazhbayev, L.Zh. Zhaparova, T.S. Zhumagalieva // Pharmaceutical Chemistry Journal. 2016. - Vol. 50, No. 9. - P. 608-612 (IP 0,461).

3 Tazhbaev Ye.M. Nanoparticles on the basis of polylactic acid and polylactic-co-glycolic acids loaded with drugs / Ye.M. Tazhbaev, M.Zh. Burkeev, L.Zh. Zhaparova, T.S. Zhumagalieva, Zh.T. Arystanova // Bulletin of the Karaganda University. Chemistry ser. - 2019. - No. 2(90). - P. 31-39.

4 Yang H.W. Potential of magnetic nanoparticles for targeted drug delivery / H.W. Yang, M.Y. Hua, H.L. Liu, C.Y. Huang, K.C. Wei // Nanotechnol. Sci. Appl. — 2012. - Vol. 5. - P. 73-86.

5 Shtilman M.I. Biodegradation of Polymers / M.I. Shtilman // Journal of Siberian Federal University. Biology. — 2015. Vol. 8, Iss. 2. - P. 113-130.

6 Fenske D.B. Liposomal nanomedicines: an emerging field / D.B. Fenske, A. Chonn, P.R. Cullis // Toxicol. Pathol. — 2008. Vol. 36, № 1. - P. 21-29.

7 Shaitan K. Computer-aided molecular design of nanocontainers for inclusion and targeted delivery of bioactive compounds / K. Shaitan, Y. Tourleigh, D. Golik, M. Kirpichnikov // J. Drug Del. Sci. Tech. - 2006. - Vol. 16. — P. $253-258$.

8 Li H. A PEDF N-terminal peptide protects the retina from ischemic injury when delivered in PLGA nanospheres / H. Li, W. Tran, Y. Hu et al. // Exp. Eye Res. - 2006. - Vol. 83, No. 4. - P. 824-833.

9 Ding C. Effect of cyclic freeze-thawing process on the structure and properties of collagen / C. Ding, M. Zhang, G. Li // Int. J. Biol. Macromol. — 2015. - Vol. 80, Iss. 1. - P. 317-323.

10 Chunhui Ruan. Substance P-modified human serum albumin nanoparticles loaded with paclitaxel for targeted therapy of glioma / Chunhui Ruan, Lisha Liu, Yifei Lu, Yu Zhang, Xi He, Xinli Chen et al. // Acta Pharm Sin B. — 2018. — Vol. 8, No. 1. - P. 85-96.

\author{
Е.М. Тажбаев, Т.С. Жумагалиева, Л.Ж. Жапарова, А.А. Агдарбек, \\ Э.Ж. Жакупбекова, Г.К. Буркеева, Б.Н. Каримова, С.Б. Жаутикова \\ Дәрілік заттарды тасымалдаудың заманауи құрал ретінде \\ PLGA негізіндегі нанобөлшектерді синтездеу және зерттеу
}

\begin{abstract}
Мақалада қатерліісікке қарсы «Тамоксифен» препаратын полилактидгликолид негізіндегі нанобөлшектерге иммобилизациялау мүмкіндігі көрсетілген. Биоыдырамалы және биоүйлесімді полимер негізіндегі нанобөлшектер эмульсия әдісімен алынған. Жақсартылған физико-химиялық көрсеткіштермен (бөлшектердің өлшемі, полидисперстілігі, байланысу және босап шығу дәрежесі, биодеградациясы) нанобөлшектерді алу үшін дәрілік заттың және тұрақтандырғыштың әртүрлі концентрациялары қолданылған. Аталған жұмыста тұрақтандырғыш ретінде поливинил спирті пайдаланылған. Динамикалық жарық шашу әдісімен алынған полимерлі нанобөлшектердің өлшемдері 226,7-397,2 нм аралығында және өлшем бойынша таралуы тар (полидисперстілік мәндері (PDI) 0,01-0,2) болды. УКспектрофотометрлік әдіспен ( $\lambda=275,5$ нм) анықталған тамоксифеннің полимермен байланысу дәрежесі шамамен 82 \% құрады және ол оның дәрілік заттардың тасымалдаушылары ретінде қолдануда болашағы зор екендігі көрсетілген. Электронды микроскопия әдісімен нанобөлшектердің формасы мен морфологиясы және биологиялық ортаны модельдейтін жағдайда полилактидликолид нанобөлшектерінен дәрілік заттың босап шығу кинетикасы зерттелген. Сонымен қатар, әртүрлі рН мәндерінде 310 К температурада тамоксифенмен иммобилизацияланған полилактидликолид нанобөлшектерінің биодеградациясының жалпы сипаттамалары вискозиметрлік әдіспен анықталған.
\end{abstract}

Кілт сөздер: нанобөлшектер, полимерлі нанобөлшектер, полилактидгликолид, тамоксифен, эмульсия әдісі, иммобилизация, дәріні тасымалдау, полимерлер.

\author{
Е.М. Тажбаев, Т.С. Жумагалиева, Л.Ж. Жапарова, А.А. Агдарбек, \\ Э.Ж. Жакупбекова, Г.К. Буркеева, Б.Н. Каримова, С.Б. Жаутикова
}

\section{Синтез и исследование наночастиц на основе PLGA как современного инструмента транспорта лекарств}

В статье показана возможность иммобилизации противоопухолевого препарата «Тамоксифен» в наночастицы полилактидгликолида. Наночастицы на основе биодеградируемого и биосовместимого полимера полилактидгликолида были получены методом простой эмульсии. Для получения наночастиц с наилучшими физико-химическими показателями (размера частиц, полидисперсности, степени связывания и высвобождения, биодеградации) были исследованы различные концентрации лекарственного 
вещества и стабилизатора. В настоящей работе в качестве стабилизатора использован поливиниловый спирт. Размеры полимерных наночастиц, полученных методом динамического светорассеяния, варьируются от 226,7 нм до 397,2 нм, с узким распределением частиц по размерам (значения полидисперсности (PDI) составили 0,01-0,2). Степень связывания тамоксифена с полимером, рассчитанная УФспектрофотометрическим методом ( $\lambda=275,5$ нм), составила около $82 \%$, что делает его перспективным при использовании для доставки лекарств. Методом сканирующей электронной микроскопии изучены форма и морфология наночастиц. Исследована кинетика высвобождения препарата из наночастиц полилактидгликолида в условиях, моделирующих биологическую среду. Кроме того, вискозиметрическим методом исследован общий характер биодеградации наночастиц полилактидгликолида, иммобилизованных тамоксифеном в разных значениях $\mathrm{pH}$ среды при температуре $310 \mathrm{~K}$.

Ключевые слова: наночастицы, полимерные наночастицы, полилактидгликолид, тамоксифен, метод простой эмульсии, иммобилизация, доставка лекарств, полимеры.

\section{References}

1 Cai, W., Gao, T., Hong, H., \& Sun J. (2008). Applications of gold nanoparticles in cancer nanotechnology. Nanotechnol. Sci. Appl., 1(1), 17-32.

2 Burkeev, M.Zh., Tazhbayev, Ye.M., Zhaparova, L.Zh., \& Zhumagalieva, T.S. (2016). Synthesis and investigation of nanoparticles of poly-d,1-lactic acid loaded with antituberculosis drug preparation «Isoniazid». Pharmaceutical Chemistry Journal, 50, 9, 608612 (IP 0,461).

3 Tazhbaev, Ye.M., Burkeev, M.Zh., Zhaparova, L.Zh., Zhumagalieva, T.S., \& Arystanova, Zh.T. (2019). Nanoparticles on the basis of polylactic acid and polylactic-co-glycolic acids loaded with drugs. Bulletin of the Karaganda University. Chemistry ser., 2(90), 31-39.

4 Yang, H.W., Hua, M.Y., Liu, H.L., Huang, C.Y., \& Wei, K.C. (2012). Potential of magnetic nanoparticles for targeted drug delivery. Nanotechnol. Sci. Appl., 5, 73-86.

5 Shtilman, M.I. (2015). Biodegradation of Polymers. Journal of Siberian Federal University. Biology, 8, 2, $113-130$.

6 Fenske, D.B., Chonn, A., \& Cullis, P.R. (2008). Liposomal nanomedicines: an emerging field. Toxicol. Pathol, 36, 1, 21-29.

7 Shaitan, K., Tourleigh, Y., Golik, D., \& Kirpichnikov, M. (2006). Computer-aided molecular design of nanocontainers for inclusion and targeted delivery of bioactive compounds. J. Drug Del. Sci. Tech., 16, 253-258.

8 Li, H., Tran, W., Hu, Y., et al. (2006). A PEDF N-terminal peptide protects the retina from ischemic injury when delivered in PLGA nanospheres. Exp. Eye Res., 83, 4, 824-833.

9 Ding, C., Zhang, M., \& Li, G. (2015). Effect of cyclic freeze-thawing process on the structure and properties of collagen. Int. J. Biol. Macromol., 80, 1, 317-323.

10 Chunhui, Ruan, Lisha, Liu, Yifei, Lu, Yu, Zhang, Xi, He, Xinli, Chen, et al. (2018). Substance P-modified human serum albumin nanoparticles loaded with paclitaxel for targeted therapy of glioma. Acta Pharm. Sin. B., 8(1), 85-96. 